\title{
INTERAKSI SOSIAL JANDA CERAI DI MASYARAKAT (STUDI DI DESA PACAREJO, SEMANU, GUNUNGKIDUL, DIY)
}

\author{
Mirza Aulia Rahmawati dan Farida Hanum \\ Jurusan Pendidikan Sosiologi, FIS, Universitas Negeri Yogyakarta \\ Email: mirzaauliarahmawati@gmail.com
}

\begin{abstract}
Abstrak
Penelitian ini bertujuan mendeskripsikan proses interaksi sosial yang dilakukan janda cerai di masyarakat desa Pacarejo, mendeskripsikan kendala- kendala yang dihadapi setelah bercerai dan strategi janda cerai dalam berinteraksi sosial di masyarakat. Analisis data menggunakan analisis model interaktif Miles dan Huberman. Hasil penelitian ini menunjukkan bahwa proses interaksi sosial yang terjadi antara janda cerai dan masyarakat berjalan dengan normal. Janda cerai tetap dilibatkan dalam setiap kegiatan di desa. Masyarakat umumnya menerima dan tidak mempermasalahkan seseorang dengan status sebagai janda cerai. Hasil penelitian juga menunjukkan bahwa terdapat kendala-kendala yang dihadapi setelah hidup sebagai janda cerai yaitu kesulitan melakukkan pekerjaan sendiri, kesulitan membesarkan anak sendiri, kesulitan memenuhi kebutuhan ekonomi, menanggung perasaan sakit hati yang tidak kunjung sembuh, dan ketidaknyamanan terhadap status baru sebagai janda cerai. Selain itu, terdapat strategi yang dilakukan oleh janda cerai di masyarakat dalam berinteraksi sosial yaitu 1) dengan menyibukkan diri sendiri dalam pekerjaan mereka, 2) tidak peduli/ membiarkan perkataan/perlakuan orang lain, 3) menerima takdir yang sudah digariskan kepada janda cerai, 4) memberikan bukti tidak bersalah apabila memiliki masalah dengan oranglain, dan 5) memperbaiki diri sendiri untuk kehidupan di masa depan.
\end{abstract}

Kata Kunci : Interaksi Sosial, Janda Cerai, Masyarakat

Abstract

This research aimed to describe the process of social interaction done by divorced widows in Pacarejo and the obstacles faced after divorcing and divorced widow strategy used. This research used Interactive analysis Miles and Huberman model. The results of this research indicate that the social interaction process that occurs between divorced widows and society runs normally. Divorced widows are still involved in every village activity. The society accept and do not care with someone's divorce status. Other obstacles faced after life as divorced widow is difficulty to do their own job, difficulty to raise own child, difficulty to fulfill the economic requirement, bearing the broken feeling, and inconvenience with new status as divorce widow. In addition, there are strategies undertaken by divorced widows in in social interaction that are 1) occupying themselves in their work, 2) not caring / letting others' words / treatment, 3) accepting destiny that has been outlined, 4) providing evidence of innocence when having problems with others, and 5) improving herselves for future life.

\section{Keywords: Social Interaction, Divorced Widow, Society}

\section{Pendahuluan}

Interaksi sosial merupakan hubungan sosial yang dinamis menyangkut hubungan antara orang perorangan, antara kelompok-kelompok manusia, maupun antara orang perorang dengan kelompok manusia (Soekanto, 2002). Interaksi sosial individu dimulai dari sebuah keluarga. Kedudukan utama setiap keluarga ialah fungsi pengantara pada masyarakat besar sebagai penghubung pribadi dengan sturktur sosial yang lebih besar (Goode, 2007). Setiap keluarga pasti memiliki impian menjadi keluarga ideal.

Interaksi Sosial Janda Cerai di Masyarakat (Studi di Desa Pacarejo, Semanu, Gunungkidul, DIY) | Mirza Aulia Rahmawati dan Farida Hanum 
Keluarga yang ideal senantiasa berlandaskan pada keharmonisan rumah tangga (Kusumardi, 2016). Akan tetapi pada kenyataannya, sebuah keluarga yang dibangun bersama bisa saja berakhir dan tidak sesuai rencana (Baron, 2004). Perceraian adalah akhir dari suatu kestabilan perkawinan, dimana pasangan suami istri kemudian berpisah dan secara resmi diakui oleh hukum yang berlaku (Endah, 2005).

Perceraian sudah familiar di seluruh tingkatan masyarakat bahkan saat ini sudah banyak angka perceraian yang terjadi khususnya di Daerah Istimewa Yogyakarta. Organisasi wanita Se-Asia Pasifik (Pan Pasifik Sount East Asia Women's Assosiation, PPSEAWA) dalam konferensinya yang ke-20 di Kuala Lumpur Malaysia, menyimpulkan bahwa kerusakan yang terjadi pada keluarga di abad ke-20 semakin memburuk. Perceraian di perkirakan sekitar 40\%-50\% generasi mendatang akan menjadi keluarga yang broken home, akibat perceraian setiap orangtua akan menjadi orang tua tunggal (single parent). Nur Abadi selaku Kepala Kantor Kementrian Agama Gunungkidul mengatakan Angka perceraian di DIY setiap tahunnya mencapai 6000 kasus. Sementara daerah yang masih terkenal memiliki jumlah angka perceraian yaitu kabupaten gunungkidul sebanyak 1000an kasus setiap tahun (2014). Selama tahun 2014, total sebanyak 5.851 keluarga DIY mengalami kegagalan atau perceraian (Linangkung, 2015). Berdasarkan data pengadilan agama wonosari, angka perceraian di Gunungkidul pada tahun 2014 mencapai 1.614, tahun 2015 mengalami penurunan menjadi 1.447 kasus, dan pada tahun 2016 turun menjadi 1.303 kasus. Meski mengalami penurunan angka perceraian, Panitera Muda Hukum Pengadilan Agama Wonosari, Muslih, (Rfk, 2017) mengatakan bahwa kasus perceraian di gunungkidul masih tinggi. Hal ini dibuktikan dengan data pada akhir juni 2017 sudah terjadi 615 kasus perceraian dengan rata-rata setiap bulan terdapat 72 kasus cerai gugat yang ditangani oleh pengadilan negeri Wonosari. Pada pembukaan Gebyar Kerukunan 2017 yang diselenggarakan Kantor Wilayah Kementerian Agama Daerah Istimewa Yogyakarta tanggal 18 Desember 2017, Menteri Agama Lukman Hakim Saifuddin juga mengaku prihatin dengan semakin tingginya angka perceraian di Indonesia (Utantoro, 2017)

Dampak dari perceraian menyebabkan seseorang menyandang status baru sebagai janda atau duda. Menurut Kamus Besar Bahasa Indonesia, Janda merupakan sebutan bagi seseorang wanita yang telah ditinggalkan suaminya dan memilih untuk hidup sendiri. Status Janda di masyarakat seringkali dipandang kurang baik, sebagian kalangan masyarakat status janda merupakan mimpi 
buruk bagi seorang wanita yang masih tinggal di lingkungan masyarakat. Seorang janda juga sering diberi label seorang wanita yang patut dikasihani dan sebagian lainnya beranggapan bahwa janda adalah seorang wanita penggoda suami orang (Triadi, 2005). Hal ini lah menyebabkan seorang wanita yang berstatus janda semakin tersudut dalam kehidupan sosialnya dikarenakan masyarakat memandang status janda sebagai cacat dalam nilai sosial terutama pada masyarakat desa yang pendidikannya masih rendah dan menganggap perceraian adalah suatu hal yang masih tabu. Perempuan biasanya mengalami kesulitan dalam melakukan berbagai aktivitasnya setelah perceraian. Bagi seorang perempuan, perubahan status dari seorang isteri menjadi seorang janda, tidaklah mudah. Disamping kecerdasan, dibutuhkan juga kepribadian yang kuat, rasa percaya diri, dan keberanian untuk mampu bertahan hidup. Apalagi di dalam masyarakat kita, begitu banyak tekanan tradisi yang mengecam perceraian (Sudarto \& Wirawan, 2000). Di satu sisi mereka dituntut untuk berperan ganda, sebagai kepala keluarga dan anggota masyarakat yang harus aktif menjalin interaksi sosial dengan masyarakat. Hal inilah yang membuat peneliti tertarik untuk meneliti lebih mendalam mengenai bagaimana "Interaksi Janda Cerai di Masyarakat"

\section{Metode}

Penelitian secara kritis yang tertuang dalam artikel ini dilakukan dengan menggunakan kajian pustaka sebagai literatur sehingga dapat mengkaji permasalahan sosial yakni Interaksi sosial yang dilakukan janda cerai di masyarakat. Penelitian ini menggunakan metode penelitian kualitatif dengan pendekatan deskriptif. Metode ini dipilih dimaksudkan untuk memahami masalah sosial janda cerai dalam konteks sosial dengan menciptakan gambaran menyeluruh dan kompleks yang disajikan, melaporkan pandangan terperinci dari para sumber informasi, serta dilakukan dalam setting yang alamiah tanpa adanya intervensi apapun dari peneliti (Herdiansyah, 2010). Subjek dalam penelitian ini yaitu seseorang yang menjadi janda karena bercerai. Seorang janda cerai yang harus tetap melanjutkan kehidupannya dengan tetap berinteraksi dengan masyarakat umum di desa Pacarejo, Semanu, Gunungkidul, Daerah Istimewa Yogyakarta. Data yang digunakan dalam penelitian ini adalah data primer dan data sekunder. Data primer dalam penelitian ini adalah data yang yang diperoleh secara langsung melalui observasi dan wawancara langsung kepada Janda Cerai di desa tersebut. Sedangkan data sekunder berasal dari dokumen berupa dokumen arsip penduduk desa setempat, studi 
kepustakaan baik dari media cetak maupun media internet yang menyajikan berbagai masalah terkait kehidupan janda cerai pasca perceraian. Pengumpulan data dilakukan dengan beberapa metode, yaitu: 1) wawancara kepada janda cerai dan warga sebagai saksi 2) observasi kegiatan janda dan lingkungannya, 3) dokumentasi sumber digital lainnya. Teknik Sampling yang digunakan adalah teknik purposeful sampling dengan strategi typical sampling yang berarti suatu strategi yang digunakan untuk kasus-kasus yang bersifat khas atau unik atau individuindividu yang memiliki karakteristik unik dalam hal ini adalah seseorang yang berstatus sebagai janda cerai di desa Pacarejo. Teknik analisis data dalam penelitian ini menggunakan analisis model interaktif Miles dan Huberman yaitu di mulai dari pengumpulan data, reduksi data, penyajian data, dan penarikan kesimpulan.

\section{Hasil dan Pembahasan}

1. Interaksi sosial yang dilakukan janda cerai di lingkungan masyarakat

Menurut Robert M.Z. Lawang dalam (Soyomukti, 2013) interaksi sosial adalah proses ketika orang-orang yang berkomunikasi saling pengaruh mempengaruhi dalam pikiran dan tindakan. Menurut Gillin dan Gillin (Soekanto, 2002: 64) ada dua penggolongan proses sosial yang timbul sebagai akibat adanya interaksi sosial, yaitu pola interaksi asosiatif (akomodasi, kerjasama dan asimilasi)dan pola interaksi disosiatif (persaingan, kontravensi, pertentangan).

\section{a. Kerjasama}

Bentuk kerjasama yang dilakukan antara para janda cerai dan masyarakat di desa Pacarejo berupa arisan, kerjabakti, PKK, dan kumpul rutinan. Janda cerai tetap diakui dan dilibatkan dalam kegiatan desa tanpa di bedakan satu sama lain. Janda cerai dan masyarakat masih menjaga hubungan komunikasi.

\section{a. Akomodasi}

Para janda cerai di desa Pacarejo menjelaskan bahwa proses menstabilkan kondisi masyarakat yaitu dengan tidak membuat masalah menjadi semakin rumit. Mundur dari konflik dengan menerima keadaan dan tidak mempedulikan perkataan orang lain adalah langkah yang tepat untuk meredakan situasi di dalam masyarakat.

b. Asimilasi

Masyarakat paham akan pentingnya toleransi, oleh karena itu sangat jarang ditemui perselisihan. Mereka memilih untuk mementingkan diri sendiri dengan bekerja lebih keras dibanding mengurusi hal yang dilakukan orang lain. Sehingga dalam kehidupan masyarakat, janda cerai dan masyarakat umum dapat hidup bersama tanpa memandang kepentingan status sosial masing- masing.

c. Persaingan

Persaingan yang terjadi antara janda 
cerai dengan masyarakat jarang sekali ditemui, karena masyarakat yang tidak terlalu peduli dengan kondisi janda cerai. Beberapa narasumber selalu menegaskan bahwa mereka selalu menerima apa yang sudah mereka miliki dan mereka berpikir untuk tidak mempedulikan orang lain yang membicarakannya di belakang.

d. Kontravensi

Janda cerai di desa Pacarejo sepakat bahwa perasaan sakit hati dan ketidaksukaan akan situasi yang terjadi pasti ada. Mengalami kepedihan hati karena ditinggalkan oleh suami adalah proses kehidupan yang berat bagi para janda cerai.

e. Konflik/pertentangan

Pertentangan yang terjadi antara janda cerai di desa Pacarejo sangatlah sedikit. Konsep hidup nrimo menjadi landasan masyarakat untuk tidak mudah terprovokasi dengan isu-isu konflik yang terjadi. Apabila ada masalah yang timbul, itu hanya sebatas kesalahpahaman antar individu dalam masyarakat.

\section{Kendala-kendala yang dihadapi oleh} para janda cerai

a. Melakukan pekerjaan sendiri

Terbiasa menjalani kehidupan bersama pasangan dan tiba-tiba harus melakukan pekerjaan seorang diri merupakan kendala yang sulit bagi janda cerai melanjutkan kehidupannya

b. Membesarkan anak sendiri

Terbiasa menjalani kehidupan bersama pasangan dan tiba-tiba harus melakukan pekerjaan seorang diri merupakan kendala yang sulit bagi janda cerai melanjutkan kehidupannya

c. Kesulitan memenuhi kebutuhan ekonomi.

Menjadi single parent adalah pekerjaan yang berat karena harus memenuhi kebutuhan ekonomi sendiri. Tidak adanya pilihan untuk menyerah pada kehidupan membuat janda cerai terus berjuang hidup dan melanjutkan kehidupannya dengan lebih baik.

d. Terus merasakan sakit hati

Perempuan ditakdirkan menjadi mudah perasa. Sehingga perempuan mudah bersedih dalam jangka waktu yang lama. Untuk itu merasakan sakit hati merupakan salah satu kendala yang dialami oleh janda cerai ketika menjalani kehidupan yang selanjutnya.

e. Ketidaknyamanan status baru

Status janda cerai adalah kendala yang pada awalnya harus di hadapi oleh para janda cerai dimanapun mereka berada dan kapanpun mereka berada meskipun ternyata lambat laun masyarakat tidak mempedulikannya lagi.

\section{Strategi para janda cerai dalam mengatasi masalah}

a. Menyibukkan diri

Strategi menyibukkan diri dengan pekerjaan membuat seseorang janda cerai melupakan sejenak masalah yang mereka miliki. Menikmati kesibukkan juga akan 
membantu mempercepat hari-hari yang dijalani. Semakin padat kegiatan yang dimiliki, kesempatan untuk memikirkan masalah semakin sedikit sehingga pikiran tidak terbebani oleh bayang-bayang masalah.

b. Tidak peduli/ membiarkan perkataan/ perlakuan orang lain

Tidak mempedulikan perkata-an/ perbuatan negatif orang lain adalah strategi janda cerai untuk terus bertahan tanpa tersakiti oleh pembicaraan orang lain dan tanpa menyakiti balik orang lain tersebut

c. Menerima takdir

Semua narasumber janda cerai di desa Pacarejo sepakat bahwa apapun kondisi yang telah menimpa kehidupannya harus mereka terima dengan lapang dada. Meyakini bahwa menerima takdir yang telah digariskan kepada mereka adalah strategi untuk bisa terus bertahan dalam kehidupan selanjutnya.

d. Memberikan bukti tidak bersalah

Masyarakat dapat membuat asumsi sendiri yang belum tentu benar adanya. Tugas yang harus di lakukan yaitu berani untuk membuktikan bahwa tidak bersalah apabila memiliki masalah dengan masyarakat. Strategi penanganan masalah dengan memberikan bukti pada orang lain, dirasa efektif karena tidak menimbulkan bantahan yang menyudutkan kondisi para janda cerai di masyarakat.

e. Memperbaiki diri sendiri

Status janda yang melekat adalah karena ketidak-mampuan dirinya menghadapi masalah di masa lalu dan merupakan takdir yang di gariskan untuk kehidupannya sehingga tidak menjadi penghalang bagi para janda cerai untuk terus berbuat lebih baik terhadap masyarakat. Strategi memperbaiki diri sendiri adalah upaya janda cerai untuk diterima di masyarakat bagaimanapun kondisinya mereka kini.

\section{Temuan Lapangan}

a. Adanya budaya nrimo

Interaksi sosial berjalan dengan normal. Semua narasumber menyebutkan bahwa hampir tidak ada masalah yang terjadi akibat status janda cerai. Masalah yang terjadi biasanya dikarenakan kesalahpaham-an antar warga mengenai kehidupan sehari-hari. Stigma negatif yang selama ini terdapat pada masyarakat umum ternyata tidak berlaku di desa Pacarejo. Hal ini disebabkan budaya nrimo yang ditanamkan oleh masyarakat desa. Hal ini selaras dengan teori interaksi sosial yang disampaikan oleh Herbert Blumer (Soyomukti, 2013) yaitu bahwa tindakan manusia terhadap sesuatu atas dasar makna yang dimiliki oleh manusia tersebut. Teori ini menjelaskan bahwa terdapat suatu pemaknaan hidup yang dimiliki oleh masyarakat yang dilaksana-kan secara bersama dalam kehidupan sosial. Konsep nrimo menjadi pemaknaan bersama masya-rakat desa Pacarejo bahwa kehidupan yang dijalani harus sesuai 
sehingga mendapat-kan kehidupan yang lebih baik.

b. Tidak ada tekanan dari masyarakat

Konsep nrimo yang di pegang oleh masyarakat maupun janda cerai menjadikan masyarakat menerima kondisi status janda cerai dan tidak mempermasalahkan hal tersebut. Adanya desas desus yang beredar dikarenakan masyarakat hanya merasa ingin tahu. Masyarakat menganggap bahwa tidak ada salahnya menjadi janda cerai karena hal itu sudah menjadi takdir bagi seseorang. Kondisi ini ternyata tidak selaras dengan pendapat Ahmad Ali Imron (Imron, 2009) dalam jurnalnya 'Pencitraan Perem-puan Pasca Perceraian Dalam Prespektif Gender' yang menjelaskan bahwa perempuan berpredikat seba-gai janda, memiliki makna negatif misalnya dianggap menjadi sampah, bekas istri, dan tidak layak dijadikan istri lagi. Masyarakat desa Pacarejo justru menganggap bahwa status janda cerai bukan masalah untuk bisa berinteraksi di masyarakat. Status janda cerai tidak menjadi penghalang bagi seseorang untuk terus berkontribusi dalam setiap kegiatan di desa. Kondisi ini menjawab alasan kabupaten Gunungkidul menjadi wilayah yang memiliki angka perceraian tertinggi. Hal ini dikarenakan oleh kondisi masyarakat yang tidak mempermasalahkan janda cerai dalam proses interaksi yangberlangsung di masyara-kat. Janda cerai menjalani kehidupan tanpa takut mendapatkan tekanan dan stigma negatif di lingkungan.

c. Adanya toleransi yang tinggi dari masayarakat

Masyarakat desa Pacarejo memiliki tingkat toleransi yang tinggi dibuktikan dengan diikutsertakannya setiap warga dalam kegiatan desa tanpa melihat status orang tersebut. Kondisi ini mengakibatkan janda cerai pada umumnya tidak merasa bersalah terhadap kondisi telah menimpa dirinya. Hal ini menjadi selaras dengan pendapat Robert M.Z Lawang (Soyomukti, 2013) yang menjelaskan bahwa dalam proses interaksi orang- orang berkomunikasi dengan saling pengaruh mempengaruhi pikiran dan tindakan. Kondisi masyarakat yang tidak memempermasalahkan status janda cerai menjadikan janda cerai juga merasa aman tinggal dilingkungan tersebut. Pengaruh yang ditimbulkan oleh sikap masyarakat menjadikan sikap janda cerai menjadi masyarakat yang biasa saja dan tidak mempedulikan status yang dimiliki.

\section{Simpulan}

Dari hasil pemaparan dalam penelitian Interaksi Janda Cerai di Masyarakat Desa Pacarejo, Semanu, Gunungkidul, DIY dapat ditarik kesimpulan sebagai berikut.

1. Hasil penelitian ini menunjukkan bahwa tidak ada masalah yang serius dalam proses interaksi sosial para janda cerai 
di masyarakat. Umumnya setelah bercerai, seorang janda cerai harus melanjutkan kehidupannya dan berinteraksi secara intim di masyarakat. Proses interaksi sosial yang terjadi pada janda cerai berjalan dengan normal (seperti biasanya). Hal tersebut disebabkan oleh adanya budaya nrimo di masyarakat yang menyebabkan interaksi janda cerai dan masyarakat berjalan dengan normal, tidak banyak perubahan antara ketika janda dan sebelum menjadi janda. Selain itu, tidak terdapat adanya tekanan dari masyarakat yang membatasi interaksi seorang janda cerai. Janda cerai tidak merasa bersalah apabila telah memutuskan untuk bercerai. Perceraian merupakan hal yang wajar apabila suatu pasangan sudah tidak memiliki kecocokan lagi sehingga perceraian atau status janda cerai tidak menjadi hal yang tabu. Dapat dikatakan bahwa status janda cerai hampir tidak menyebabkan masalah di masyarakat. Apabila ada masalah yang timbul, itu hanya sebatas kesalahpahaman antar individu dalam masyarakat. Sehingga janda cerai tetap dilibatkan dalam setiap kegiatan yang dilaksanakan di desa. Masyarakat umumnya menerima dan tidak mempermasalahkan seseorang dengan status sebagai janda cerai.
2. Hasil penelitian juga menunjukkan bahwa sebagian besar janda cerai memiliki anak sehingga mereka dapat dikatakan sebagai orangtua tunggal (single parent) yang harus bekerja keras menghidupi keluarganya. Oleh karena itu, kendala yang cukup berat untuk mereka hadapi adalah harus melakukkan pekerjaan sendiri, kesulitan membesarkan anak sendiri, dan kesulitan dalam memenuhi kebutuhan ekonomi. Di samping itu, kendala yang dirasakan oleh janda cerai adalah perasaan sakit hati yang tidak kunjung sembuh, dan ketidaknyamanan terhadap status baru sebagai janda cerai.

3. Setelah mengetahui kendala yang dihadapi oleh janda cerai, penelitian ini juga menjelaskan mengenai strategi yang dilakukan oleh janda cerai di masyarakat dalam berinteraksi yaitu 1) dengan menyibukkan diri sendiri dalam pekerjaan mereka, 2) tidak peduli/ membiarkan perkataan/ perlakuan orang lain, 3) menerima takdir yang sudah digariskan kepada janda cerai, 4) memberikan bukti tidak bersalah apabila memiliki masalah dengan oranglain, dan 5) memperbaiki diri sendiri untuk kehidupan di masa depan.

\section{Ucapan Terimakasih}

Terima kasih disampaikan kepada semua pihak yang telah mendukung 
penulisan artikel dan kepada tim redaksi Jurnal Dimensia yang telah menerbitkan tulisan ini.

\section{Daftar Pustaka} . (1997). Hasil Konferensi. Organisasi Pan Pasifik Sount East Asia Women's Assosiation, PPSEAWA ke-20 di Kuala Lumpur Malaysia.https://www.academia.edu/ . Diunduh pada 22 Februari 2018. . (2014). Gunungkidul Tertinggi Di DIY Soal Perceraian Pasutri. http://www.info-jogja.com/. Diunduh pada 22 Februari 2018

Baron, R. A \& Byrne, D. 2004. Psikologi Sosial. Jakarta: Erlangga

Endah, G.N., 2005, "Faktor-faktor Penyebab Perceraian dan Dampaknya Terhadap Kehidu-pan Keluarga (Studi Kasus di Desa Nagrak Utara, Kecamatan Nagrak Kabupaten Sukabumi”, Skripsi, Yogyakarta: Program Studi Bimbingan dan Konseling, Jurusan Psikologi Pendidikan dan Bimbingan, Fakultas IImu Pendidikan, UNY

Goode, William J. (2007). Sosiologi Keluarga. Jakarta PT: Bumi Aksara.

Herdiansyah, Haris. (2010). Metodologi Penenlitian Kualitatif untuk IImu-IImu Sosial. Jakarta: Salemba Humanika Imron, Ahmad Ali. (2009). Pencitraan Perempuan Pasca Perceraian Dalam Perspektif Gender. Jurnal EGALITA. Volume 4 Nomor 1, 2009

Kusumaredi, Lulu. (2016). Keluarga Ideal. http://ntb.bkkbn.go.id/. Diunduh pada 22 Februari 2018

Linangkung, Erfanto. (2015). Angka Perceraian di DIY Capai 5.851

Kasus. Terdapat di https://daerah.sindonews.com/.Diund uh pada 22 Februari 2018

Rfk. (2017). Kasus Perceraian di Gunungkidul Masih Tinggi. http://jogja.tribunnews.com/. Diunduh pada 22 Februari 2018

Soekanto, Soerjono. (2002). Sosiologi Suatu Pengantar. Jakarta: PT.
RajaGrafindo Persada

Sudarto, L dan Wirawan, H. E. (2000). Penghayatan Makna Hidup Perempuan Bercerai. Jurnal IImiah Psikologi "ARKHE" Thn. 6/No. 23/2001.

Soyomukti, Nurani. (2013). Pengantar Sosiologi: Dasar Analisis, Teori, Pendekatan Menuju Analisis Masalah-Masalah Sosial, Perubahan Sosial, \& Kajian-Kajian Strategis. Yogyakarta: Ar-ruzz Media

Tim penyusun Kamus Pusat Bahasa. (2015). Kamus Besar Bahasa Indonesia. Jakarta: Balai Pustaka Triadi, Ganjar. (2005). Saat Cerai Menjadi Pilihan. Yogyakarta: Dozz Publishing Utantoro, Agus. 2017. Menag Prihatin Angka Perceraian Makin Tinggi. http://www.mediaindonesia.com/. Diunduh pada 22 Februari 2018

Interaksi Sosial Janda Cerai di Masyarakat (Studi di Desa Pacarejo, Semanu, Gunungkidul, DIY) | Mirza Aulia Rahmawati dan Farida Hanum 